\title{
Changes in glaciers in Hidden Valley, Mukut Himal, Nepal Himalayas, from 1974 to 1994
}

\author{
Koji Fujita, ${ }^{1}$ Masayoshi Nakawo, ${ }^{1}$ Yoshiyuki Fujer,${ }^{2}$ Prem Paudyal ${ }^{3}$ \\ ${ }^{1}$ Institute for Hydrospheric-Atmospheric Sciences, Nagoya University, Chikusa-ku, Nagoya 464-01, Japan \\ ${ }^{2}$ National Institute of Polar Research, Ilabashi-ku, Tokyo 173, Japan \\ ${ }^{3}$ Department of Hydrology and Meteorology, Ministry of Water Resources, HMG of Nepal, P.O. Box 406, Kathmandu, Nepal
}

\begin{abstract}
Glaciological investigations were carried out in 1994 on the glaciers in Hidden Valley, Mukut Himal, Nepal Himalayas, in order to make a comparison with observations made in 1974 . Most of the glaciers were found to have retreated by $30-60 \mathrm{~m}$ in terminus elevation over the 20 years between the two studies. Rikha Samba Glacier, the longest glacier in the valley, has retreated by about $200 \mathrm{~m}$. The areal average of the amount of surface lowering and the volume loss of the glacier was estimated to be $12.6 \mathrm{~m}$ ice equivalent and $13 \%$ of the total mass, respectively. The annual mass balance of $-0.55 \mathrm{~m} \mathrm{a}^{-1}$ water equivalent was obtained as an average for 20 years, which is one of the largest negative values amongst small glaciers of the world.
\end{abstract}

\section{INTRODUCTION}

The shrinkage of small glaciers and ice caps has significantly contributed to sea-level rise over the past 100 years in association with the recent warming. Meier (1984) estimated the average mass balance of glaciers in the PamirKarakoram-Himalayan region to be $-0.31 \mathrm{ma}^{-1}$ water equivalent (w.e.) over the previous 100 years. The estimate was based on a relationship between mass balance and annual mass-balance amplitude. The amplitude for this region, however, was derived by reference only to two particular glaciers. Also, most of the glaciers in the Himalayas are of a summer-accumulation type: the major accumulation and ablation take place simultaneously during the summer. Their mass-balance regimes could therefore be different from those for winter-accumulation-type glaciers which are abundant in most regions throughout the world (Ageta and Higuchi, 1984).

Although several studies on the fluctuations of glacier termini in the Himalayas have been made (e.g. Mayewski and Jeschke, 1979; Fushimi and Ohata, 1980; Higuchi and others, 1980; Yamada and others, 1992; Kadota and others, 1993), long-term (a few decades) mass-balance data are limited. However, by examining the volume changes of glaciers in the region, it should be possible to estimate their average mass balances and examine their recent behaviour in the Himalayas.

Glaciological research work began on the glaciers in Hidden Valley, Mukut Himal, in 1974. During that work, mass balance, glacier flow and terminus elevations were observed (Fujii and others, 1976; Nakawo and others, 1976). In order to assess the changes in the glaciers over the 20 years since 1974, we carried out fieldwork in October 1994 (Fujii and others, 1996) as part of the Cryosphere Research Expedition in the Himalayas (CREH).

In this paper, the average mass balance during the past 20 years has been estimated using CREH data and com- pared with several decadal scale mass-balance averages of glaciers throughout the world.

\section{FIELDWORK IN 1974}

Hidden Valley is located in the northern part of the central Nepal Himalayas $\left(28^{\circ} 50^{\prime} \mathrm{N}, 83^{\circ} 30^{\prime} \mathrm{E}\right)$. The climatic conditions around the valley are very dry (Shrestha and others, 1976; Nepal, Ministry of Water Resources, 1988). There are 11 glaciers in the valley and their locations are shown in Figure 1. With the exception of glacier G2, which is highly debris-covered in its ablation zone, the glacier surfaces are relatively smooth and debris-free.

The elevations of the termini of glaciers G2, G3, G4, G5, G7, G8, G9 and G10 were measured using an altimeter. Rikha Samba Glacier (G5), the longest glacier in the valley, was closely observed. Nakawo and others (1976) measured the transverse surface profile of the glacier along line $\mathrm{A}$ (near the terminus), along line $\mathrm{C}$ (around the equilibriumline altitude (ELA)) and along lines D and E (in the accumulation zone) (Fig. 2). In addition, they made a detailed map of the terminus area by plane-table survey.

\section{FIELDWORK IN 1994 AND RESULTS}

In 1994, the termini of glaciers G2, G4, G5, G8, G9 and G10 were remeasured using a Thommen altimeter. The terminus altitudes obtained in 1974 and 1994 are compared in Table l, where a retreating trend can be seen for glaciers G5, G8, G9 and G10. In contrast, glaciers G2 and G4 appear to have advanced. However, it is unlikely that the terminus of glacier G2 has moved lower, because no movement of the ice was detected in 1974 (Nakawo and others, 1976). This condition is also implied by the presence of a thick debris cover. The terminus of glacier G4 is in contact with the terminus of glacier G5, with a medial moraine between them. Therefore, it is considered that the nominal advance of glacier 


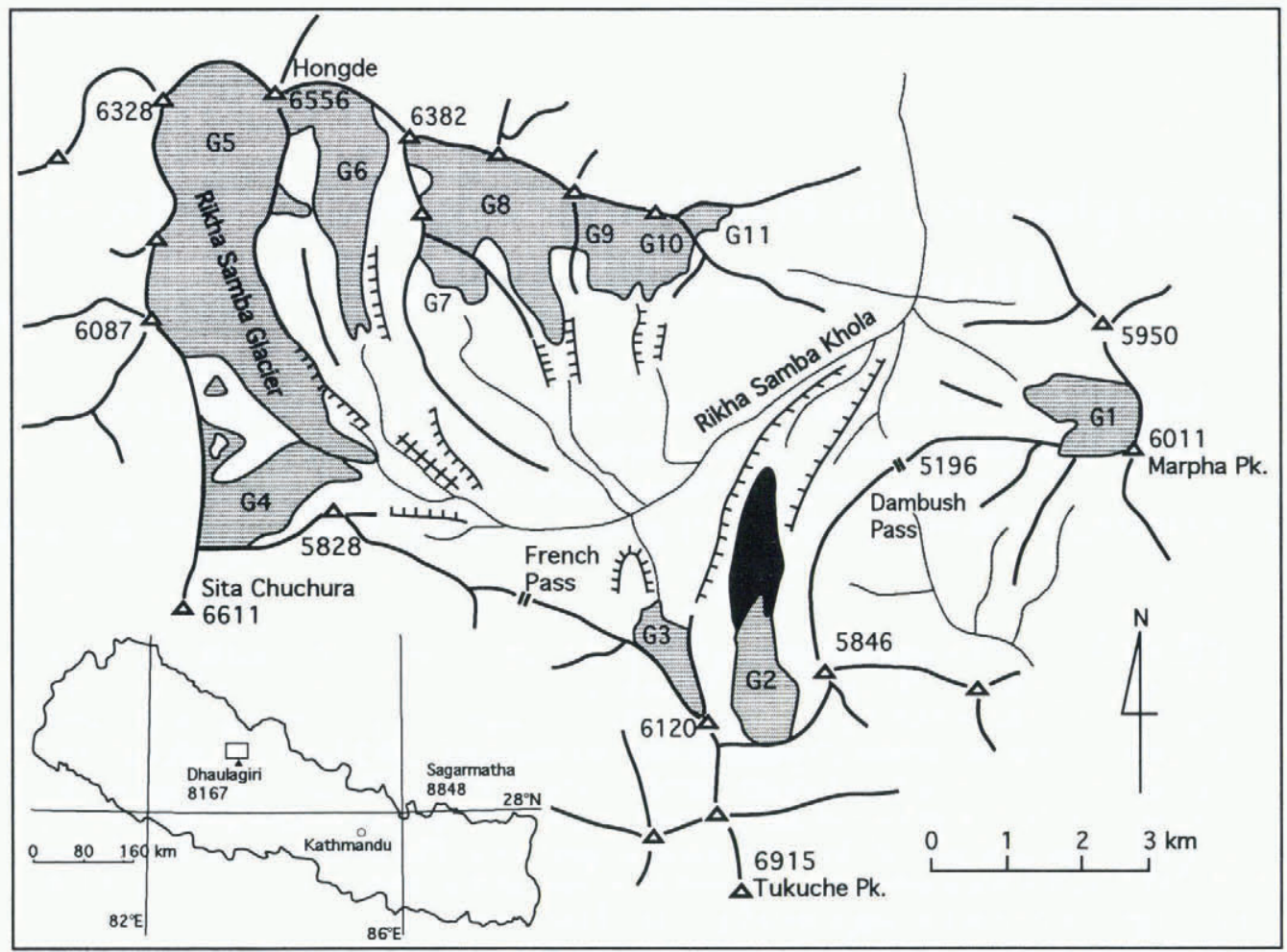

Fig. 1. Location of the glaciers in Hidden Valley, Mukut Himal. The shaded area denotes glaciers in Hidden Valley. The dark part of glacier $G 2$ denotes the debris-covered area.

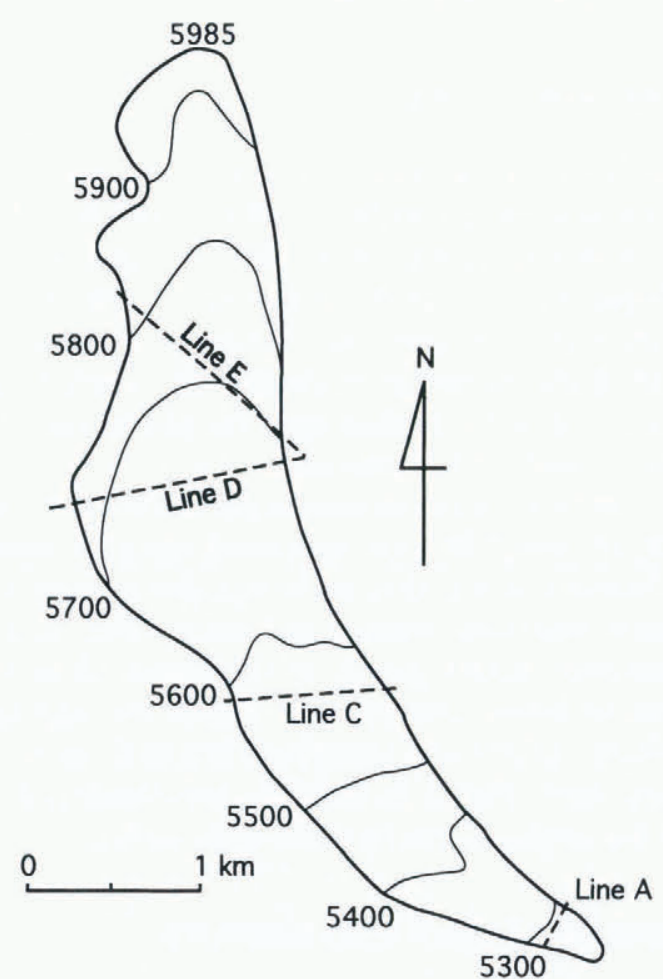

Fig. 2. Rikha Samba Glacier in 1974 showing the locations of the survey lines.

G4 could be due to shrinkage of glacier G5. Although the measurement was by altimeter, which uses air pressure and is not so reliable, the termini of the glaciers have apparently retreated and the bedrock has reappeared during the last 20 years as shown, for example, in Figure 3.

The terminus of Rikha Samba Glacier (G5) was resurveyed using a laser range-finder and theodolite (Wild T1600). Figure 4 shows maps of the terminus in 1974 (a) and in 1994 (b). The distance between benchmarks BM-A
Table 1. Altitudes of glacier termini in 1974 and 1994 measured using an altimeter

\begin{tabular}{cccc}
\hline Glacier & '1974 & 1994 & Difference \\
& m a.s.l. & m a.s.1. & $\mathrm{m}$ \\
\hline G2 & 5043 & 5017 & -27 \\
G4 & 5350 & 5300 & -50 \\
G5 & 5245 & 5275 & 30 \\
G8 & 5327 & 5362 & 35 \\
G9 & 5499 & 5559 & 60 \\
G10 & 5421 & 5480 & 59 \\
\hline
\end{tabular}

and BM-A0 were slightly different between the two sets of observations. The difference could be due to inaccuracy of the 1974 map, which was made by plane-table surveying. Nonetheless, Figure 4 shows clearly that the ice mass of the glacier near the terminus has disappeared in the 20 years between the surveys. Figure 5 shows the change in the surface profile along the longitudinal transect labeled X in Figure 4. It is clear that surface lowering of about $40 \mathrm{~m}$ and terminus retreat of about $200 \mathrm{~m}$ have taken place during 1974-94.

The surface profiles along lines C (around the ELA), D and $\mathrm{E}$ (in the accumulation zone) were remeasured using the same survey instrument (Wild T1600), and the ice thickness was also measured using a $5 \mathrm{MHz}$ radio-echo sounder. In the accumulation zone (lines D and $\mathrm{E}$ ), the surface has lowered by $15-20 \mathrm{~m}$ during the past 20 years but no appreciable surface lowering was detected around the ELA (line C), as shown in Figure 6.

Figure 7 shows the change in surface elevation from 1974 to 1994 along the central flowline; the ice thickness obtained in 1994 and the areal distribution of the glacier in 1974 were digitized from Figure 2. The surface lowering above 


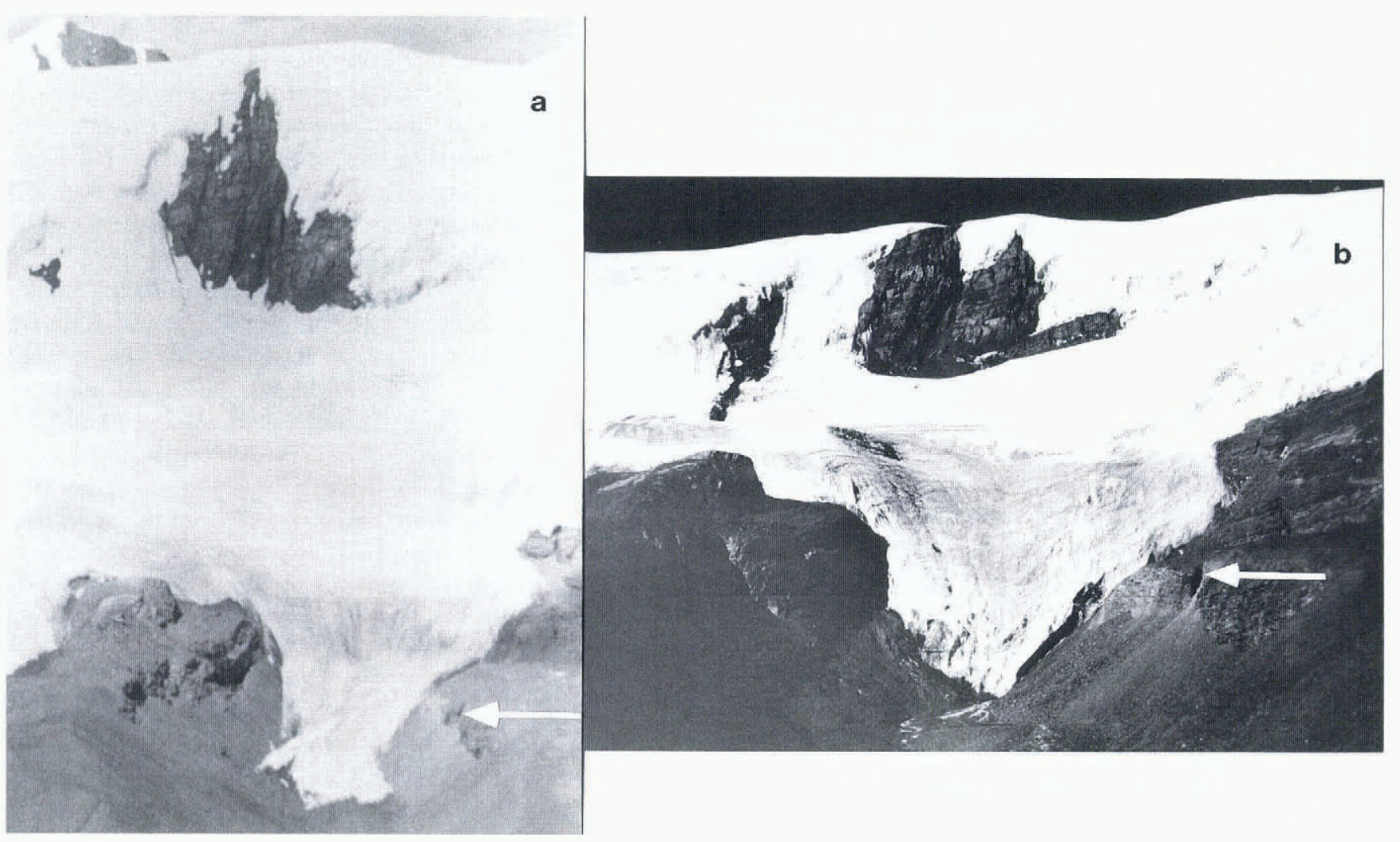

Fig. 3. Photographs of glacier G10 in 1974 (a) and 1994 (b). In both photographs the arrows denote the same rock outcrop, although the places from which the photographs were taken are different.

$5700 \mathrm{~m}$ a.s.l. was assumed to average $10 \mathrm{~m}$, because the thickness change could be reduced to zero at the uppermost point of the glacier from $20 \mathrm{~m}$ at line E. The average surface lowering for the whole glacier area is calculated to be $12.6 \mathrm{~m}$
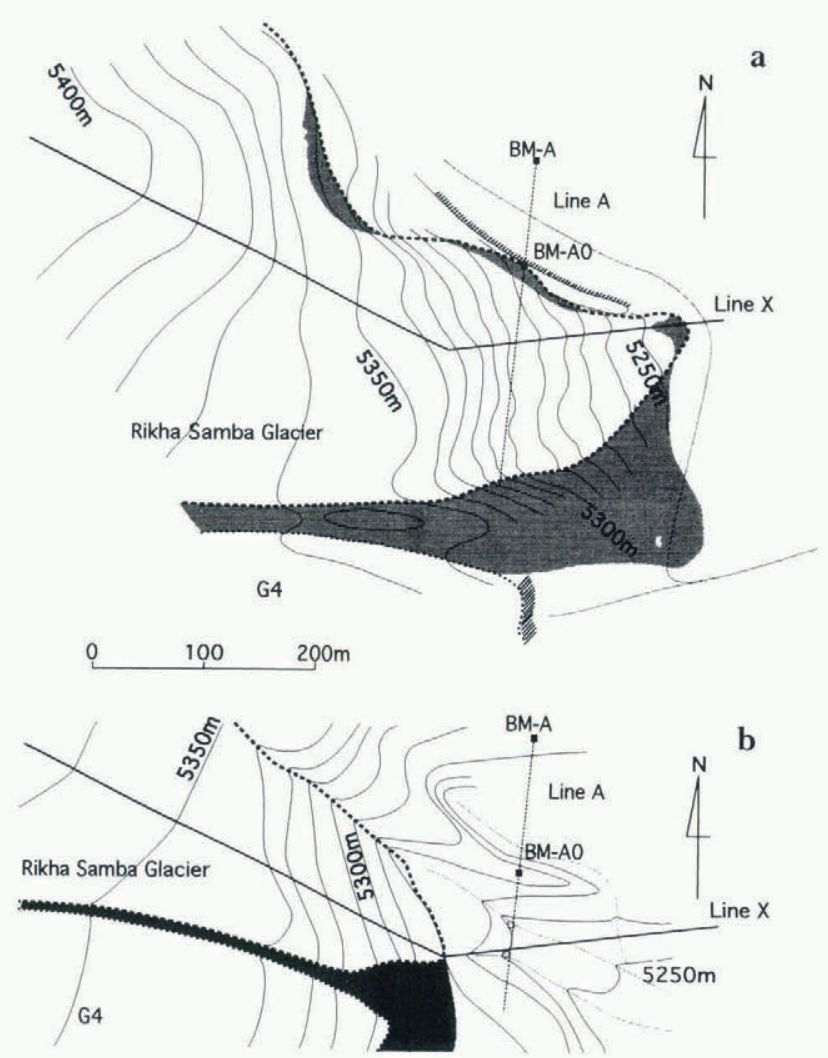

Fig. 4. Map of the terminus of Rikha Samba Glacier: (a) 1974, afler. Nakawo and others (1976), and (b) 1994, the present survey. Broken line, shaded area and solid squares represent the boundary of the glacier, debris-covered part and benchmarks, respectively, in each figure.

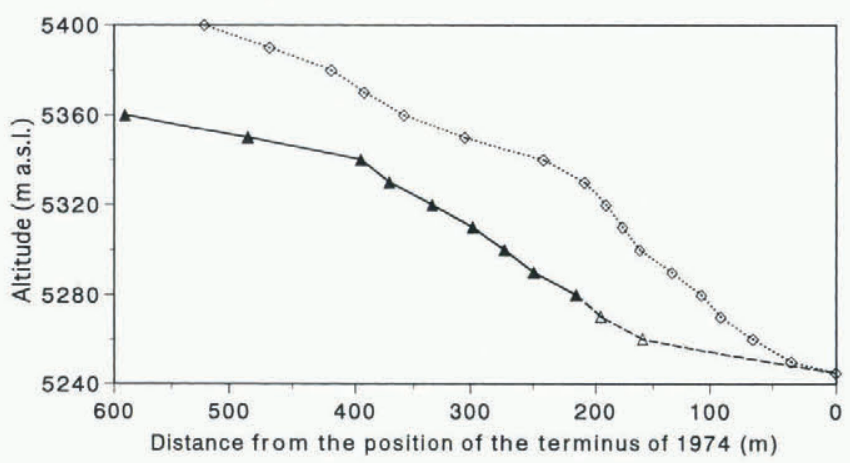

Fig. 5. Surface profile for 1974 (open squares), 1994 ( solid triangles) and bedrock (open triangles) along line $X$ near the terminus of Rikha Samba Glacier.

ice equivalent during the last 20 years. By assuming the ice depth, based on limited observational data, the total volume of the glacier is $46.2 \times 10^{7} \mathrm{~m}^{3}$ and the volume loss during 20 years is $6.0 \times 10^{7} \mathrm{~m}^{3}$ or $13 \%$ of the total volume.

The surface profiles measured in 1994 were very accurate (roughly $\pm 0.05 \mathrm{~m}$ ) using a laser range-finder. For the 1974 observations, however, the error was estimated to be $\pm 0.45 \mathrm{~m}$. Accordingly, the volume loss in 20 years would be $(6.0 \pm 1.0) \times 10^{7} \mathrm{~m}^{3}$. However, the percentage volume loss would be associated with a larger error, because the still-undetermined ice thickness in the accumulation area as shown in Figure 7 would lead to greater uncertainty about the total ice mass of the glacier.

\section{DISGUSSION}

Figure 8 shows the average mass balance $\left(\mathrm{mw}^{\mathrm{s}} \mathrm{e} . \mathrm{a}^{-1}\right.$ ) of glaciers selected from IAHS (ICSI)-UNEP-Unesco (Müller, 1977; Haeberli, 1985; Haeberli and Müller, 1988; Haeberli 


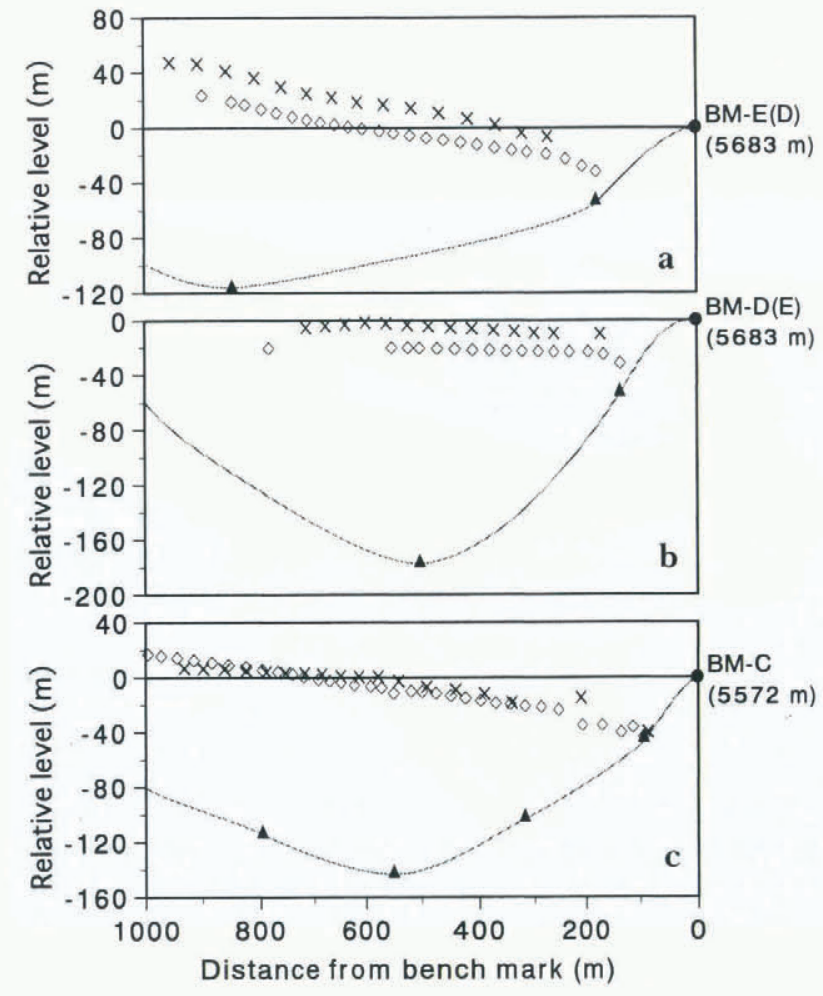

Fig. 6. Surface profiles for 1974 (crosses) and 1994 (squares) and bedrock (triangles) along lines $E(a)$ and $D(b)$ in the accumulation zone and line C around the ELA (c) of Rikha Samba Glacier looking upstream. The solid circle denotes the

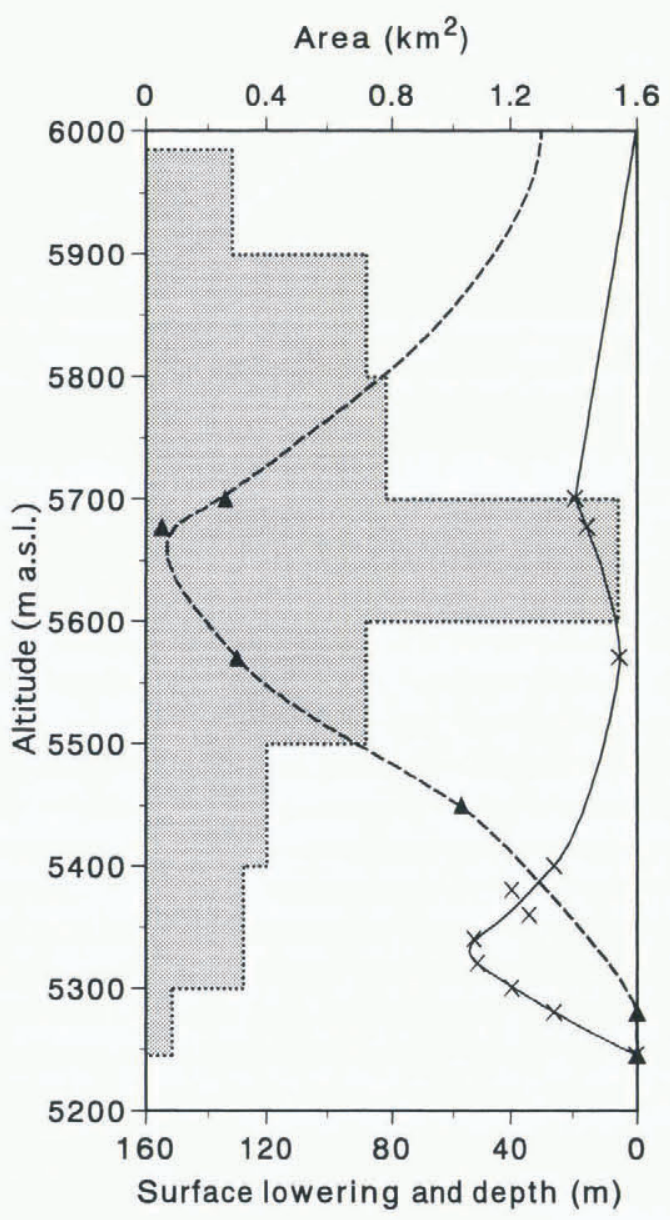

Fig. 7. Altitudinal distribution of the surface lowering (crosses) during 1974-94 and the ice depth (triangles) in 1994 along the central flowline and areal distribution in 1974 (shaded). and Hoelzle, 1993), Glacier AX010 in Shorong Himal, east Nepal (Kadota and others, 1993), and Rikha Samba Glacier. All the mass-balance data are for the past 10-20 years, including the $1970 \mathrm{~s}$. Mass-balance data are not available for 26 glaciers including Rikha Samba Glacier. For those glaciers, the average annual mass balance was calculated from the difference in their volume during a certain period using an ice density of $870 \mathrm{~kg} \mathrm{~m}^{-3}$.

This figure shows that the mass balance of Rikha Samba Glacier $\left(-0.55 \mathrm{mw}^{\left.-\mathrm{e} . \mathrm{a}^{-1}\right)}\right.$ is one of the largest negative values amongst small glaciers in the world. The average mass balance of $-0.55 \mathrm{~m}$ w.e. a ${ }^{-1}$ we obtained is also more negative than that estimated by Meier $\left(1984 ;-0.31 \mathrm{~m}\right.$ w.e. $\left.\mathrm{a}^{-1}\right)$ for the Pamir-Karakoram-Himalayan region. It could indicate either that Meier's estimate was too small for this region or that the shrinkage of the glaciers in this region has accelerated during recent decades, since his estimate is for the past 100 years, whereas ours is for the past 20 years. Kadota and others (1993) have pointed out that glacier AX010 in Shorong Himal, east Nepal, had retreated drastically between 1989 and 1991 at a rate faster than in 1978-89. It is possible that shrinkage of Rikha Samba Glacier has recently accelerated.

Meier (1984) has discussed the mass-balance variation during the past 100 years by using a relationship between the annual mass-balance amplitude $\left(a_{\mathrm{m}}\right)$ and the long-term mass balance $\left(b_{1}\right)$. He defined $a_{\mathrm{m}}$ and assumed a relationship between $a_{\mathrm{m}}$ and $b_{1}$ as:

$$
\begin{aligned}
a_{\mathrm{m}} & =\left(b_{\mathrm{w}}-b_{\mathrm{s}}\right) / 2 \\
b_{\mathrm{l}} / a_{\mathrm{m}} & =-0.23
\end{aligned}
$$

where $b_{\mathrm{w}}$ is the winter balance and $b_{\mathrm{s}}$ (normally negative) is the summer balance. Winter and summer balances are respectively used instead of annual accumulation and ablation. In the Himalayan region, however, it is of little use to define winter and summer balances, because major accumulation and ablation occur simultancously in the summer monsoon season (Ageta, 1983). It is therefore better to use the annual accumulation and ablation for $b_{\mathrm{w}}$ and $b_{\mathrm{s}}$ in Equation (1) in order to represent the mass gradient, an expression of climatic sensitivity of glaciers: (a) glaciers with a larger mass-balance gradient, which should have a larger $a_{\mathrm{m}}$, are more sensitive to a change in ELA than smaller ones; (b) continental-type glaciers with a small $a_{\mathrm{m}}$ often have cold accumulation zones in which atmospheric warming does not lead to an increase in mass loss but to firn warming.

The relationship between $a_{\mathrm{m}}$ and $b_{1}$ is examined using 51 selected glaciers from IAHS (ISCI)-UNEP-Unesco (Müller, 1977; Haeberli, 1985; Haeberli and Müller, 1988; Haeberli and Hoelzle, 1993) and AX010 from Kadota and others (1993) (Fig. 9). The time period considered for these data is more than 5 years, including the $1970 \mathrm{~s}$. The $a_{\mathrm{m}}$ for glacier AX010 and that for Rikha Samba Glacier were estimated from Ageta (1983) and Fujii and others (1976), respectively. Both glacier AX010 and Rikha Samba Glacier in the Himalayas showed very negative mass balances for corresponding annual mass-balance amplitudes $\left(a_{\mathrm{m}}\right)$.

It can be seen in Figure 9a that glaciers with a large $a_{\mathrm{m}}$ also show a large positive $b_{1}$, although those glaciers with a positive $b_{1}$ are few. When $b_{1}$ is negative, the negative correlation can be seen between $b_{1}$ and $a_{\mathrm{m}}$ (Fig. 9b). The average values for the fraction $b_{1} / a_{\mathrm{m}}$ and the correlation coefficient for negative $b_{1}$ are -0.28 and -0.55 , respectively. The value 


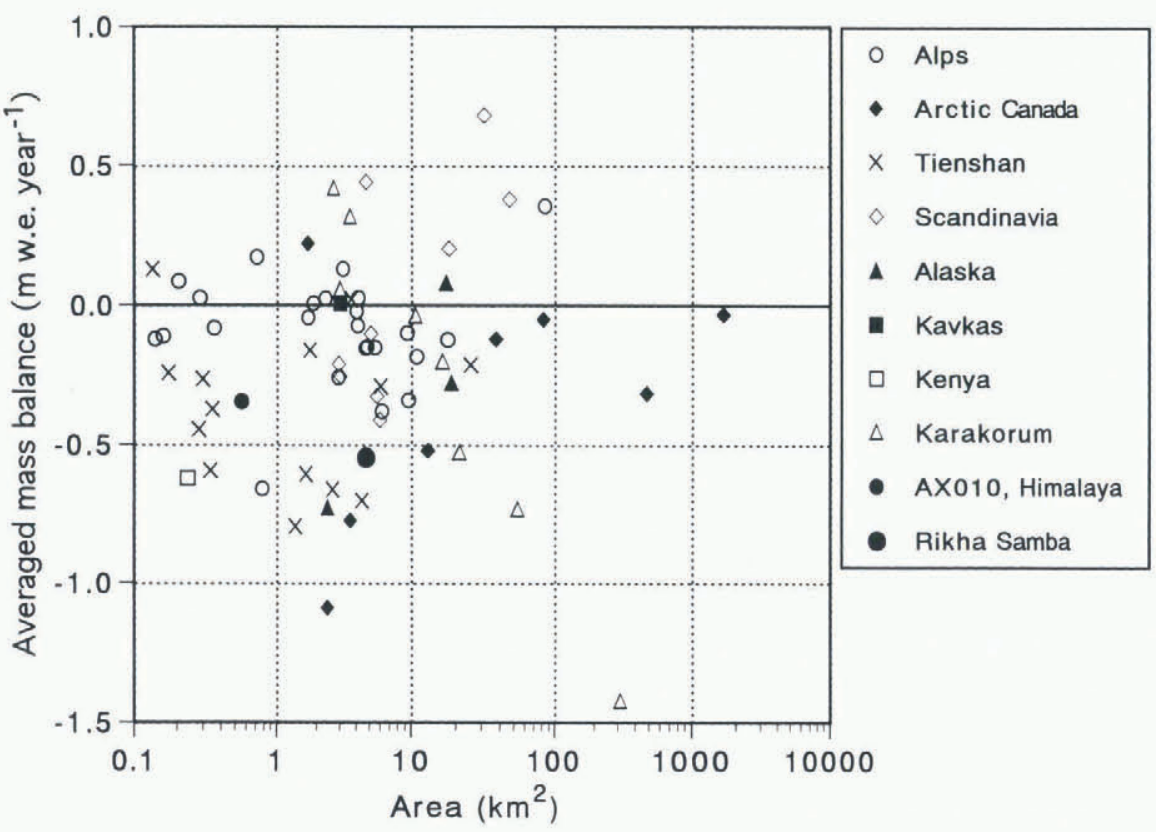

Fig. 8. The averaged mass balance for the last 10-20 years of 72 glaciers throughout the world.

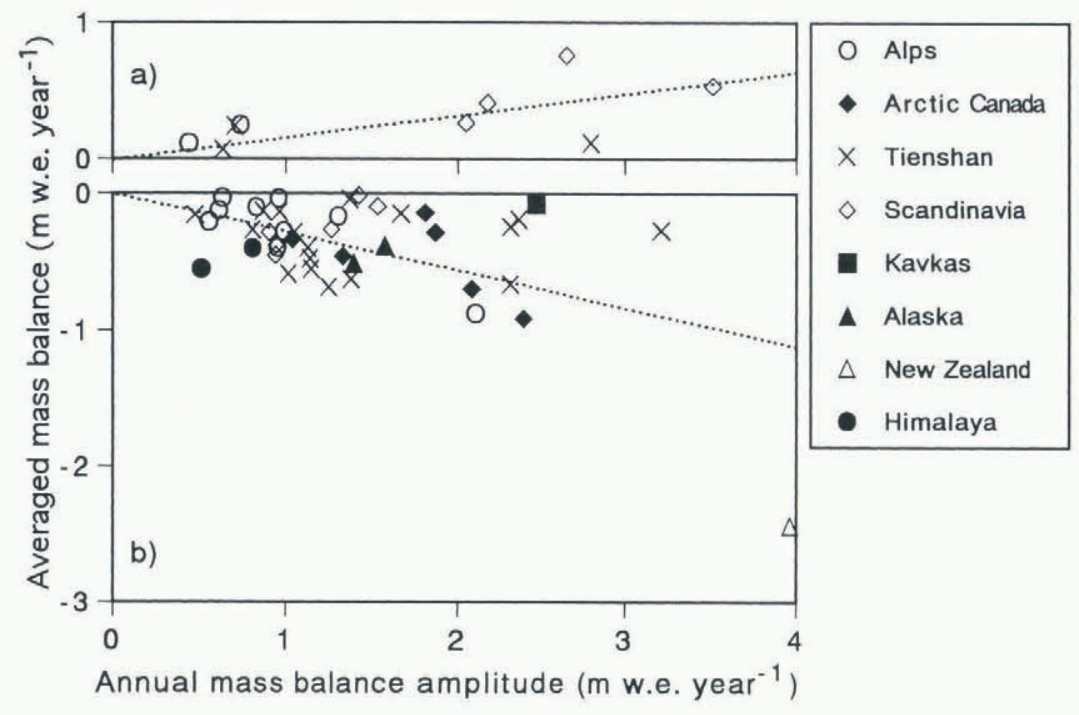

Fig. 9. The relationship between the annual mass-balance amplitude $\left(a_{\mathrm{m}}\right)$ and the average mass balance $\left(b_{\mathrm{l}}\right)$ during the recent few decades for 53 glaciers throughout the world. Each regression line is shown (a) for positive $b_{1}\left(b_{1 /} a_{\mathrm{m}}\right.$ is 0.16; $R$ is 0.63$)$ and for (b) negative $b_{1}\left(b_{1} / a_{\mathrm{m}}\right.$ is -0.28 ; $R$ is -0.55$)$.

of -0.28 differs somewhat from but is similar to that of Meier $(1984 ;-0.23)$ for the long-term trend. It would indicate that glaciers with a large $a_{\mathrm{m}}$ have shrunk more sensitively due to the recent warming.

Rikha Samba Glacier is a continental-type glacier having cold temperatures in the accumulation zone $\left(-4.9^{\circ} \mathrm{C}\right.$ at $23.25 \mathrm{~m}$ depth; $5740 \mathrm{~m}$ a.s.l.; Fujii and others, 1996) and its mass-balance amplitude is relatively small $a_{\mathrm{m}}$ is $0.5 \mathrm{~m}$ w.e. $\mathrm{a}^{-1}$; Fujii and others, 1976). The estimated 20 years mass balance, however, shows a large negative value $\left(-0.55 \mathrm{~m}\right.$ w.e. $\left.\mathrm{a}^{-1}\right)$. Surface snow thickness of Rikha Samba Glacier was a few tens of centimeters, even in the accumulation zone $(5740 \mathrm{~m}$ a.s.l.). Such a thin snow layer in the upper accumulation zone has also been observed in the central Tibetan Plateau (Fujita and others, 1996). Fujita and others (1996) suggested that such a thin snow layer is favorable to making ice cold in winter but has a disadvantage for accumulation; after complete melting of the thin surfacesnow layer, surface ice with a lower albedo would start to melt drastically with strong solar radiation at a low latitude even at the upper accumulation zone. These glaciers would therefore have possibly large negative mass balances even though they belong to the continental type.

The $b_{1}$ for Rikha Samba Glacier is one of the largest negative values in the world, although it has a relatively small $a_{\mathrm{m}}$. Ageta (1983) has pointed out that the accumulation of the summer-accumulation-type glaciers would decrease drastically with an increase in summer temperature: the accumulation becomes small even though the precipitation is very large, because the precipitation becomes rain with warmer conditions. So the mass balance would become largely negative owing to a decrease in accumulation as well as an increase in ablation for a warm summer. It is therefore considered that summer-accumulation-type glaciers would have a strongly negative mass balance even if accumulation and ablation (annual massbalance amplitude) were to be small. The strongly negative mass balance found for Rikha Samba Glacier, in spite of the small annual mass-balance amplitude, could be attributed to the special characteristics of summer-accumulation-type 
glaciers, although the average mass balance for a somewhat short time period may not be an expression of global climate change but of regional climate variability. The contribution of the Himalayan glaciers to sea-level rise could therefore be much larger than the previous estimate associated with recent global warming, because most of the glaciers in the Himalayas belong to the summer-accumulation type.

\section{ACKNOWLEDGEMENTS}

We should like to express our thanks to the staff of the Department of Hydrology and Meteorology, Ministry of Water Resources, HMG of Nepal. We are obliged to the people who assisted in this research programme in Nepal. This is a contribution from the Glaciological Expedition in Nepal (GEN). We are grateful to Dr W. Haeberli, Department of Geography, University Zürich-Irchel, for critically reviewing this paper. The overall cost of the research was in part supported by a grant-in-aid for scientific research (project No. 06041051) from the Ministry of Education, Science, Sports and Culture, Japanese Government.

\section{REFERENCES}

Ageta, Y. 1983. [Characteristics of mass balance of the summer-accumulation type glacier in the Nepal Himalaya. 1. Mass balance of Glacier AX010 in east Nepal.] Seppyo, J. Jpn. Soc. Snow Ice, 45 (2), 81 90. [In Japanese with English summary.]

Ageta, Y. and K. Higuchi. 1984. Estimation of mass balance components of a summer-accumulation type glacier in the Nepal Himalaya. Geogr. Ann., 66A (3), 249-255.

Fujii, Y., M. Nakawo and M. L. Shrestha. 1976. Mass balance studies of the glaciers in Hidden Valley, Mukut Himal. Seppyo, J. Jpn. Soc. Snow Ice, 38 (Part I), Special Issue, 17-21.

Fujii, Y., K. Fujita and P. Paudyal. 1996. Glaciological research in Hidden
Valley, Mukut Himal in 1994. Bull. Glacier Res. 14, 7-11.

Fujita, K., K. Scko, Y. Ageta, J. Pu and Y. Tandong. 1996. Superimposed ice in glacier mass balance on the Tibetan Plateau. J. Glaciol., 42 (142), 454-460.

Fushimi, H. and T. Ohata. 1980. Fluctuations of glaciers from 1970 to 1978 in the Khumbu Himal, east Nepal. Seppyo, J. Jpn. Soc. Snow Ice, 41 (Part IV), Special Issue, 71-81.

Haeberli, W., ed. 1985. Fluctuations of glaciers $1975-1980$ (Vol. IV). Paris, International Commission on Snow and Ice of the International Association of Hydrological Sciences/Unesco.

Haeberli, W. and M. Hoclzle, eds. 1993. Fluctuations of glaciers $1985-1990$ (Vol. VI). Wallingford, Oxon., IAHS Press; Nairobi, UNEP; Paris, Unesco.

Haeberli, W. and P. Müller, eds. 1988. Fluctuations of glaciers 1980-1985 ( Vol.V). Paris, International Commission on Snow and Ice of the International Association of Hydrological Sciences, United Nations Environment Programme and Unesco.

Higuchi, K. and 8 others. 1980. Glacier inventory in the Dudh Kosi region, east Nepal. International Association of Hydrological Sciences Publication 126 (Riederalp Workshop 1978 - World Glacier Inventory), 95- 103.

Kadota, T., K. Seko and Y. Ageta. 1993. Shrinkage of glacier AX010 since 1978, Shorong Himal, east Nepal. International Association of Hydrological Sciences Publication 218 (Symposium at Kathmandu 1992 - Snow and Glacier Hydrology), 145-154.

Mayewski, P. A. and P. A. Jeschke. 1979. Himalayan and trans-Himalayan glacier fluctuations since A.D. 1812. Arct. Alp. Res., 11 (3), 267-287.

Meier, M. F. 1984. Contribution of small glaciers to global sea level. Science. 226 (4681), 1418-1421.

Müller, F. ed. 1977. Fluctuations of glaciers 1970-1975 (Vol. III). Paris, International Commission on Snow and Ice of the International Association of Hydrological Sciences/Unesco.

Nakawo, M., Y. Fujii and M. L. Shrestha. 1976. Flow of glaciers in Hidden Valley, Mukut Himal. Seppyo, 7. Jpn. Soc. Snow Ice, 38 (Part I), Special Issue, 39-43.

Nepal. Ministry of Water Resources. 1988. Climatological records of . Nepal 19851986. Kathmandu, Nepal, Ministry of Water Resources. Department of Hydrology and Meteorology.

Shrestha, M. L., Y. Fujii and M. Nakawo. 1976. Climate of Hidden Valley, Mukut Himal during the monsoon in 1974. Seppyo, J. Jpn. Soc. Snow Ice, 38 (Part I), Special Issue, 105-108.

Yamada, T. and 7 others. 1992. Fluctuations of the glaciers from the 1970 s to 1989 in the Khumbu, Shorong and Langtang regions, Nepal Himalayas. Bull. Glacier Res. 10, 11-19. 